\title{
Distribution pattern of GFP (green fluorescent protein) in a bivalve- inhabiting hydrozoan, Eutima japonica (Leptomedusae: Eirenidae)
}

\section{$\operatorname{AUTHOR}(S)$ :}

Kubota, Shin; Nomaru, Eriko; Uchida, Hiroko; Murakami, Akio

\section{CITATION:}

Kubota, Shin ... [et al]. Distribution pattern of GFP (green fluorescent protein) in a bivalveinhabiting hydrozoan, Eutima japonica (Leptomedusae: Eirenidae). Journal of the Marine Biological Association of the United Kingdom 2010, 90 (7): 1371-1374

\section{ISSUE DATE:}

2010-07-14

URL:

http://hdl.handle.net/2433/187920

\section{RIGHT:}

(c) Marine Biological Association of the United Kingdom 2010 


\title{
Distribution pattern of GFP (green fluorescent protein) in a bivalve-inhabiting hydrozoan, Eutima japonica (Leptomedusae: Eirenidae)
}

\author{
SHIN KUBOTA ${ }^{1}$, ERIKO NOMARU ${ }^{2}$, HIROKO UCHIDA ${ }^{2}$ AND AKIO MURAKAMI ${ }^{2}$ \\ ${ }^{1}$ Seto Marine Biological Laboratory, Field Science Education and Research Center, Kyoto University, Shirahama, Nishimuro, \\ Wakayama 649-2211, Japan, ${ }^{2}$ Kobe University Research Center for Inland Seas, Iwaya 2746, Awaji, Hyogo, 656-401, Japan
}

\begin{abstract}
Bright green auto-fluorescence was observed in the umbrellar margin, umbrellar marginal warts, tentacular bulbs, tentacles, and manubrium of laboratory-reared immature (1-14 days old) medusae of Eutima japonica from Japan and China. In vivo microscopic fluorescence spectra showed that the green fluorescence was similar to that of green fluorescent protein (GFP) found in Aequorea victoria, although the maximum emission wavelength $(503 \mathrm{~nm})$ was slightly bluer. No fluorescence was detected in the cirri, statocysts, radial canals, velum, or subumbrella of the medusae. The fluorescence distribution pattern in $\mathrm{E}$. japonica more closely resembles that of Eugymnanthea inquilina from the Mediterranean Sea than that of Japanese Eugymnanthea japonica, which is the derived species of $\mathrm{E}$. japonica. This suggests that the common fluorescence pattern is convergently evolved in the former two species, perhaps owing to the as yet unclarified physiological and/or ecological function of GFP and/or GFP-like proteins.
\end{abstract}

Keywords: fluorescence pattern and spectra, green fluorescent protein (GFP), hydromedusa, Eutima, Eugymnanthea, systematics

Submitted 29 June 2009; accepted 1 September 2009; first published online 14 July 2010

\section{INTRDDUCTION}

The two species of the genus Eugymnanthea are commensal hydroids associated mainly with Mytilus galloprovincialis and other bivalves inhabiting shallow waters. The medusae of E. inquilina occurring in the Mediterranean Sea and E. japonica from Japanese waters are morphologically similar and sometimes hard to distinguish (Kubota 2000, 2004; Govindarayan et al., 2005). Kubota et al. (2008), however, found that these medusae are remarkably different in their microscopic fluorescence patterns and thus are completely separable; namely, bright green auto-fluorescence was detected in the umbrellar margin of a spent medusa of E. inquilina, in contrast to subumbrellar fluorescence in E. japonica. The fluorescence distribution patterns were thus shown to be a reliable taxonomic character in some hydroids.

In the present study, we examined the fluorescence pattern of Eutima japonica, one of the ancestral and most closely related species to Eugymnanthea japonica (Kubota, 2000). We assumed that the fluorescence pattern of Eutima japonica would be more similar to that of Eugymnanthea japonica inhabiting the same geographical region than to that of E. inquilina remotely isolated from both of them. Moreover, we checked whether the auto-fluorescence is due to green fluorescent protein (GFP) or another fluorescent substance, as essential data for the future study of this novel character.

Corresponding author:

S. Kubota

Email: shkubota@medusanpolyp.mbox.media.kyoto-u.ac.jp

\section{MATERIALS AND METHODS}

Two populations of Eutima japonica associated with Mytilus galloprovincialis were observed, one from Minami-Sanriku town, Miyagi Prefecture, Japan, collected in August 2004, and the other from Tsingtao, China, collected in September 2007. Polyps were cultured at the Seto Marine Biological Laboratory in Shirahama town, Wakayama Prefecture, Japan, being kept in filtered seawater and fed with newly hatched Artemia larvae for two weeks in the former case, and for seven months in the latter. The released medusae were identified on the basis of their morphology as the northern form of Eutima japonica (Kubota, 1992, 2008). Seven one-day-old medusae (six Japanese specimens and one Chinese specimen) and eight 14-day-old immature medusae (seven Japanese specimens and one Chinese specimen) were observed under a fluorescent microscope (BX 51 , Olympus, Japan) with excitation of ultraviolet $(330-385 \mathrm{~nm})$ and blue-violet $(420-440 \mathrm{~nm})$ wavelength, at the Kobe University Research Center for Inland Seas. In vivo fluorescence spectra were measured with a fluorescence microscope equipped with an ultra-high sensitivity multi-channel photodiode array detector (PMA-11, Hamamatsu Photonics, Japan) (Murakami et al., 2004). The fluorescence pattern of a medusa of Eugymnanthea japonica originating from Mytilus galloprovincialis collected at Shirahama, Japan, in June 2007 was also confirmed for comparison (Kubota et al., 2008).

\section{RESULTS}

Bright green auto-fluorescence was detected in different parts of body such as the umbrellar margin, umbrellar marginal 

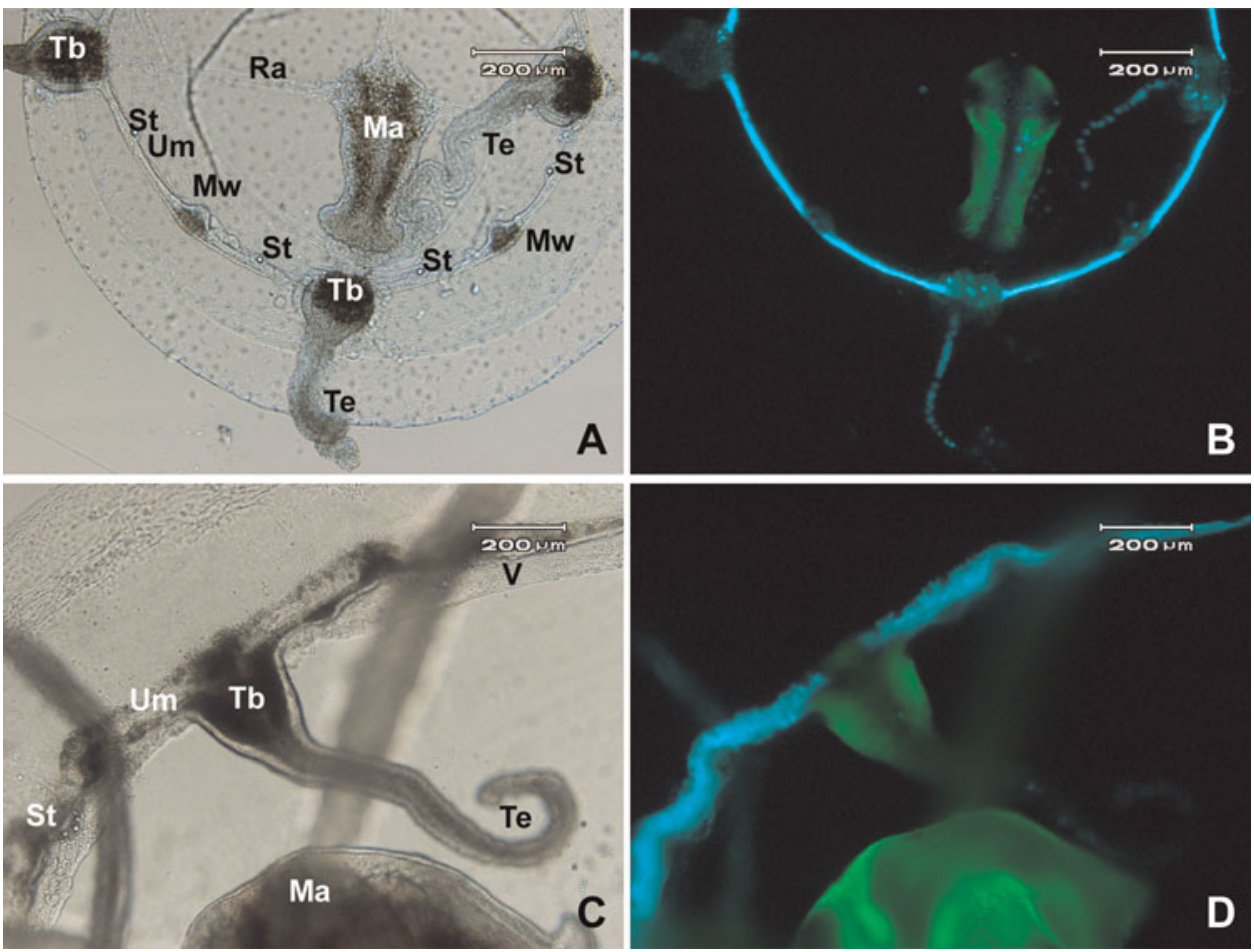

Fig. 1. Photomicrographs of immature medusae of Eutima japonica from Miyagi Prefecture, Japan (A, B: 1-day-old; C, D: 14-day-old), showing various body parts: tentacles $(\mathrm{Te})$, tentacular bulbs $(\mathrm{Tb})$, umbrellar marginal wart $(\mathrm{Mw})$, manubrium (Ma), umbrellar margin (Um), velum (V), and statocysts (St). Auto-fluorescence images under blue light excitation $(B, D)$ and transmitted light images $(A, C)$ of the same two individuals.

warts, tentacular bulbs, tentacles, and manubrium of the laboratory-reared immature (1-14 days old) medusae of Eutima japonica from Japan (13 specimens) and China (two specimens) (Figure $1 \mathrm{~A}-\mathrm{D})$. Fluorescence emission spectra with an emission maximum at $503 \mathrm{~nm}$ indicated the contribution of GFP (Figure 2). No fluorescence was observed in the remaining body parts such as cirri, statocysts, radial canals, or subumbrella of these medusae (Figure $1 \mathrm{~A}-\mathrm{D}$ ). In contrast, in the subumbrella of a mature medusa of Eugymnanthea japonica from Japan (Figure $3 \mathrm{~A}-\mathrm{B}$ ), green fluorescence was observed as has been described previously (Kubota et al., 2008), but in a different pattern than that shown in a photomicrograph in the previous paper (Kubota et al., 2008; Figure 1D).

\section{DISCUSSIDN}

Microscopic fluorescence spectra indicated that the green auto-fluorescence of Eutima and Eygymnanthea may be derived from GFP. Green fluorescent protein was first discovered in the hydromedusan Aequorea (Shimomura et al., 1962) and has also been found in other cnidarians, i.e. sea anemones and corals (Ward, 1998; Shimomura, 2006), as well as amphioxus (Deheyn et al., 2007). The physiological and ecological functions of GFP and GFP-like proteins (Belogurova et al., 2008) have not been resolved to date, but these substances are presumed to function in the generation of warning or masking coloration and can be used as fluorescent markers in cell and molecular biology (Yanushevich et al., 2005). In bioluminescent medusae emission spectra will differ according to ecological factors, as was shown by
Haddock \& Case (1999), but bivalve-inhabiting hydrozoans such as Eutima japonica, Eugymnanthea japonica and Eugymnanthea inquilina are not bioluminescent species (Kubota, unpublished data).

Green fluorescent protein distribution patterns in tissues and organs of some hydromedusans are variable among closely related species, as reported by Kubota et al. (2008) and this study. The fluorescence distribution pattern of Eutima japonica more closely resembles that of Eugymnanthea inquilina from the Mediterranean Sea than that of the Japanese Eugymnanthea japonica, even though

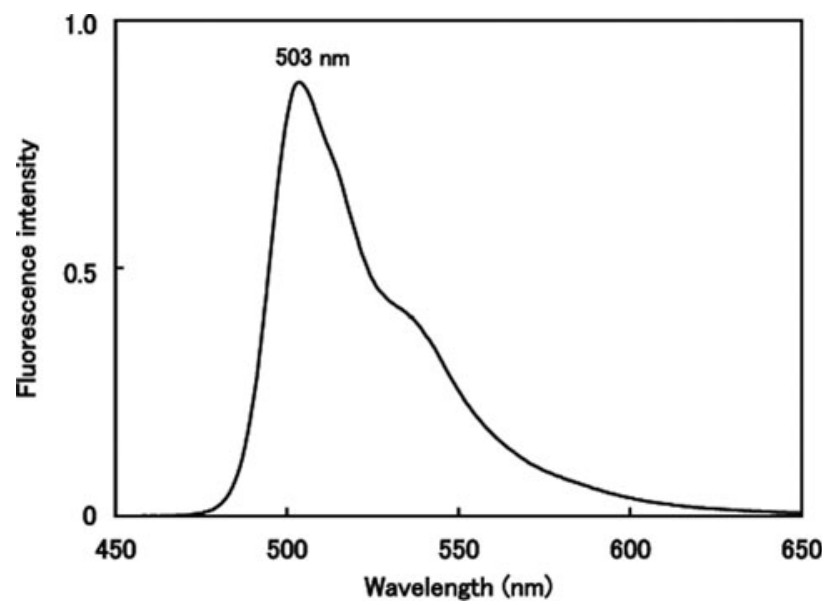

Fig. 2. In vivo fluorescence emission spectra of green fluorescent protein in a 14-day-old immature medusa of Eutima japonica from Tsingtao, China; excitation wavelength: $435 \mathrm{~nm}$. 

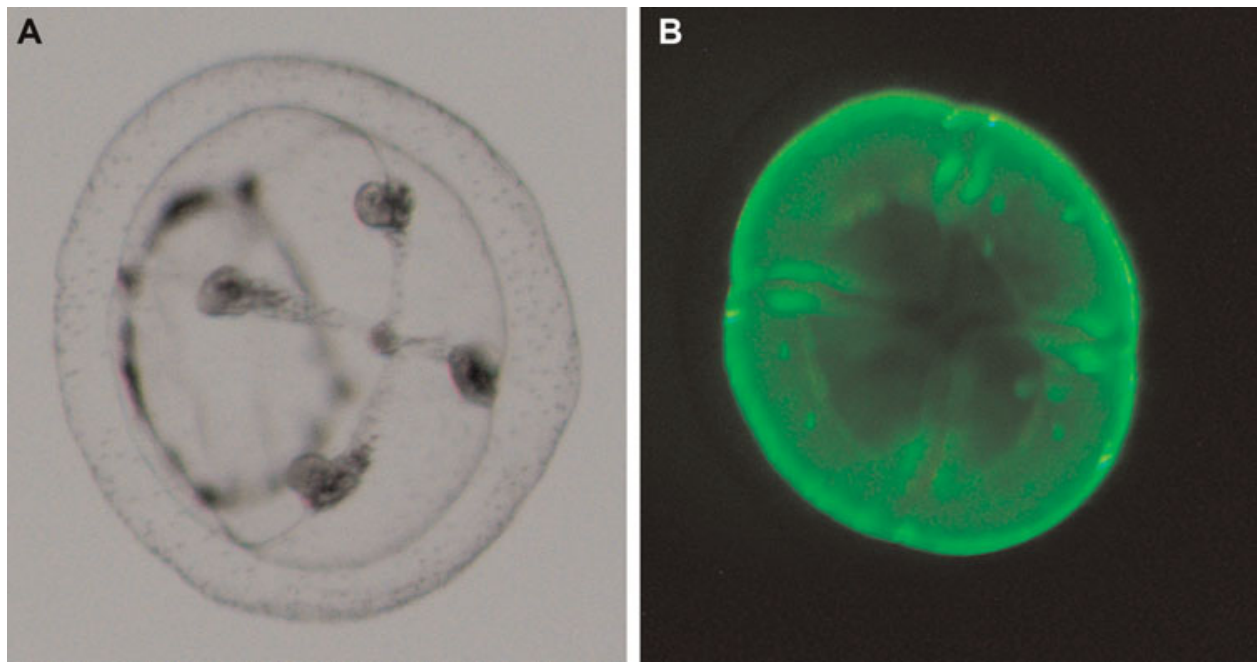

Fig. 3. Microphotographs of a spent medusa of Eugymnanthea japonica from Shirahama, Wakayama Prefecture, Japan. Bright-field image (A) and auto-fluorescence image under blue light excitation (B) of the same individual of which umbrellar diameter is $0.93 \mathrm{~mm}$.

the latter represents an advanced form derived from the present ancestral species. This is against our expectation and implies that the similar fluorescence pattern may be a convergent character related to its physiological and/ or ecological role, although the real function of the fluorescence has almost never been resolved. Although the distribution patterns of GFP may have no phylogenetic significance, they are useful and important as taxonomic markers.

The maximum emission wavelength of GFP is different in each of the three geographically widely separated species of amphioxus studied by Deheyn et al. (2007). Similarly, the maximum emission wavelength of GFP in the present species $(503 \mathrm{~nm})$ is slightly different from that of Aequorea victoria and Renilla reniformis $(508-509 \mathrm{~nm})$, as well as those of the hydromedusae of Halistaura, Mitrocoma, and Phialidium (497-498 nm) (Shimomura et al., 1962; Ward, 1998; Shimomura, 2006). Such differences among species imply that the maximum emission wavelength of the GFP is species-specific, at least within a limited taxonomic group such as Leptomedusae. Further study is required, including a comparison of the maximum emission wavelength of GFP and the fluorescence pattern among ordinary medusae with tentacles and a mouth like the present species.

\section{ACKNDWLEDGEMENTS}

We thank Dr Katsuhiko Tanaka for his kind help in collecting mussels from Miyagi Prefecture, Japan, and Dr Mark J. Grygier for his critical reading and emendation of the manuscript.

\section{REFERENCES}

Belogurova N.V., Kudryasheva N.S., Alieva R.R. and Sizykh A.G. (2008) Spectral components of bioluminescence of aequorin and obelin. Journal of Photochemistry and Photobiology B: Biology 92, 117-122.
Deheyn D., Kubokawa K., McCarthy J.K., Murakami A., Porrachia M., Rouse G.W. and Holland N.D. (2007) Endogenous green fluorescent protein (GFP) in amphioxus. Biological Bulletin. Marine Biological Laboratory, Woods Hole 213, 95-100.

Govindarajan A.F., Piraino S., Gravili C. and Kubota S. (2005) Species identification of bivalve-inhabiting marine hydrozoans of the genus Eugymnanthea. Invertebrate Biology 124, 1-10.

Haddock S.H.D. and Case J.F. (1999) Bioluminescence spectra of shallow and deep-sea gelatinous zooplankton: ctenophores, medusae and siphonophores. Marine Biology, Berlin 133, 571-582.

Kubota S. (1992) Four bivalve-inhabiting hydrozoans in Japan differing in range and host preference. Scientia Marina 56, 149-159.

Kubota S. (2000) Parallel, paedomorphic evolutionary processes of the bivalve-inhabiting hydrozoans (Leptomedusae, Eirenidae) deduced from the morphology, life cycle and biogeography, with special reference to taxonomic treatment of Eugymnanthea. Scientia Marina 64, Supplement 1, 241-247.

Kubota S. (2004) Some new and reconfirmed biological observations in two species of Eugymnanthea (Hydrozoa, Leptomedusae, Eirenidae) associated with bivalves. Biogeography 6, 1-5.

Kubota S. (2008) Life cycle of a bivalve-inhabiting hydrozoan, Eutima japonica (Hydrozoa, Leptomedusae) in Tsingtao, China and determination of its form by culture. Bulletin of the Biogeographical Society of Japan 63, 145-149. [In Japanese with English summary.]

Kubota S., Pagliara P. and Gravili C. (2008) Fluorescence distribution pattern allows to distinguish two species of Eugymnanthea (Leptomedusae: Eirenidae). Journal of the Marine Biological Association of the United Kingdom 88, 1743-1746.

Murakami A., Miyashita H., Iseki M., Adachi K. and Mimuro M. (2004) Chlorophyll $d$ in an epiphytic cyanobacterium on red algae. Science 303,1633 .

Shimomura O. (2006) Bioluminescence: chemical principles and methods. New Jersey: World Scientific Publishing Company, 470 pp.

Shimomura O., Johnson F.H. and Saiga Y. (1962) Extraction, purification and properties of aequorin, a bioluminescent protein from the luminous hydromedusan, Aequorea. Journal of Cellular and Comparative Physiology 59, 223-239.

Ward W.W. (1998) Biochemical and physical properties of green fluorescent protein. In Green Fluorescent Protein: Properties, 
Applications, and Protocols. In Chalfie M. and Kain S. (eds) Methods in cell biology. New York: Wiley-Liss, pp. 45-75.

and

Yanushevich Y.G., Shagin D.A., Fradkov A.F., Shakhbazov K.S., Barsova E.V., Gurskaya N.G., Labas Y.A., Matz A.V., Lukyanov K.A. and Lukyanov S.A. (2005) Spectral diversity among members of the green fluorescent protein family in hydroid jellyfish (Cnidaria, Hydrozoa). Russian Journal of Bioorganic Chemistry 31, 43-47.

\section{Correspondence should be addressed to:}

S. Kubota

Seto Marine Biological Laboratory

Field Science Education and Research Center

Kyoto University, Shirahama, Nishimuro

Wakayama 649-2211

Japan

email: shkubota@medusanpolyp.mbox.media.kyoto-u.ac.jp 